\title{
Uji Ketahanan Klon Kentang Hasil Pesilangan Atlantic x Repita terhadap Penyakit Hawar Daun Phytophthora infestans
}

\author{
Helmi Kurniawan ${ }^{1}$, Ineu Sulastrini ${ }^{1}$ dan Tarkus Suganda ${ }^{2}$ \\ ${ }^{1}$ Balai Penelitian Tanaman Sayuran \\ Jln. Tangkuban Perahu No. 517, Lembang, Bandung Barat 40391 \\ ${ }^{2}$ Departemen Hama dan Penyakit Tumbuhan, Fakultas Pertanian, Universitas Padjadjaran \\ Kampus Jatinangor, Jatinangor 45363 \\ Alamat korespondensi: tarkus.suganda@gmail.com
}

\begin{abstract}
Resistance Test of Potato Clones Derived from Crossing of Atlantic $\mathbf{x}$ Repita to Late Blight (Phytophthora infestans)
\end{abstract}

Late blight, incited by Phytophthora infestans is the most destructive disease of potato. The management that is effective and environmentally-friendly is the use of resistant variety. The objective of this study was to test the resistance of the six potato clones (AR 04, AR 05, AR 06, AR 07, AR 08 and AR 09) derived from crossing var. Atlantic x var. Repita to late blight caused by $P$. infestans. Var. Atlantic, Repita and Granola were used as susceptible, resistant and susceptible but the most-grown variety, respectively. Field test was located in Ciwidey, one of the potato growing center where late blight is endemic since potatoes are continuously grown. The treatments were arranged in a randomized block design with 3 replicates. The result showed that clones AR 07 and AR 08 were more resistant than the other potato clones, but it still below the resistance level var. Repita. However, based on statistical test on the diseases development (AUDPC), clone AR 08 could be categorized as resistant, equal with of the resistance level of var. Repita.

Keywords: Potato clones, Rsistance, $P$. infestans

\begin{abstract}
ABSTRAK
Penyakit hawar daun yang disebabkan Phytopthora infestans merupakan penyakit utama pada tanaman kentang. Pengendalian yang efektif dan ramah lingkungan adalah dengan penanaman varietas tahan. Penelitian ini bertujuan untuk menguji ketahanan 6 klon kentang (AR 4, AR5, AR6, AR7, AR 8, dan AR9) yang merupakan hasil persilangan antara var. Atlantic (produksi tinggi tetapi rentan) dengan var. Repita, sebagai tetua tahan terhadap penyakit hawar daun yang disebabkan oleh $P$. infestans. Varietas Atlantic, Repita dan Granola digunakan sebagai pembanding. Pengujian ketahanan dilakukan di Ciwidey, yang merupakan salah satu sentra produksi kentang di Jawa Barat dan endemik penyakit hawar daun. Perlakuan ditata menggunakan Rancangan Acak Kelompok dengan 3 ulangan. Hasil penelitian menunjukkan bahwa klon AR 07 dan Klon AR 08 memiliki ketahanan yang lebih baik dibanding klon-klon kentang lainnya, namun tingkat ketahanannya masih di bawah cv Repita. Namun, berdasarkan uji statistik terhadap nilai perkembangan penyakit (AUDPC) klon AR 08 dapat dikategorikan tahan, sama dengan derajat tahan var. Repita.
\end{abstract}

Kata Kunci: Klon kentang, Ketahanan, $P$. infestans

\section{PENDAHULUAN}

Penyakit hawar daun yang disebabkan oleh oomisetes $P$. infestans merupakan penyakit yang paling merugikan pada tanaman kentang di seluruh dunia (Sedláková et al., 2011). Kehilangan hasil yang diakibatkan oleh penyakit ini dapat mencapai 60 -
80\% (Kusmana, 2003), bahkan pada serangan yang sangat parah dapat mengakibatkan kehilangan hasil sampai $100 \%$.

Sebagian besar dari luasan pertanaman kentang di Indonesia berada pada dataran tinggi yang memiliki curah hujan, suhu lingkungan yang rendah dan kelembaban yang cukup tinggi. 
Intensitas penyakit hawar daun semakin meningkat pada musim penghujan dengan kelembaban yang tinggi (Hariyadi \& Koentjoro, 1996). Kondisi tersebut sangat kondusif bagi perkembangan penyakit hawar daun yang disebabkan oleh $P$. infestans. Temperatur dan kelembaban merupakan dua faktor penting dalam produksi sporangia $P$. infestans. Pembentukan sporangia terjadi secara optimum pada temperatur $18-22{ }^{\circ} \mathrm{C}$ dengan kelembaban relatif 100\% (Sedláková et al., 2011).

Di seluruh pertanaman kentang di dunia, pengendalian penyakit hawar daun Phytophthora mengandalkan penggunaan fungisida sintetik (Song et al., 2003). Namun demikian, dengan kemampuannya untuk menjadi resisten terhadap bahan aktif fungisida, strategi pengendalian yang paling baik untuk penyakit hawar daun Phytophthora adalah secara terpadu, termasuk penggunaan resistensi tanaman (Rietman et al., 2012; Listanto dkk., 2013). Sebagaimana terhadap bahan aktif fungisida, terhadap gen resistensi pun, $P$. infestans mudah membentuk ras-ras baru yang dapat mematahkan gen resistensi yang digunakan. Oleh karena itu, program pemuliaan tanaman untuk merakit varietas kentang yang memiliki ketahanan terhadap penyakit hawar daun yang disebabkan oleh $P$. infestans senantiasa dilakukan. Hal ini dilakukan karena tingginya keragaman genetik dari $P$. infestans yang dapat mematahkan ketahanan suatu varietas sehingga ketahanan varietas kentang harus terusmenerus dimutakhirkan.

Dalam upaya untuk mengembangkan varietas kentang yang tahan, telah dilakukan persilangan antara var. Atlantic dengan var. Repita. Varietas Atlantic merupakan kultivar yang memiliki produktivitas yang tinggi, disukai oleh konsumen dan petani namun rentan terhadap penyakit hawar daun $P$. infestans. Sementara itu, varietas Repita memiliki derajat ketahanan yang baik terhadap $P$. infestans.

Dari persilangan yang telah dilakukan, diperoleh 6 klon kentang. Tulisan ini merupakan laporan hasil uji ketahanan keenam klon hasil persilangan tersebut terhadap penyakit hawar daun $P$. infestans.

\section{BAHAN DAN METODE}

Bahan percobaan yang digunakan yaitu 6 klon hasil persilangan antara var. Atlantic dengan var. Repita, yaitu AR 4, AR5, AR6, AR7, AR 8, dan AR9. Sebagai kultivar pembanding digunakan var. Atlantic dan Repita sebagai tetua, serta var. Granola yang merupakan varietas kentang yang paling banyak ditanam oleh petani kentang di Indonesia. Dengan demikian, terdapat 9 perlakuan yang ditata berdasarkan Rancangan Acak Kelompok (RAK) dengan tiga ulangan, dengan jumlah tanaman per plot sebanyak 30 tanaman.

Uji ketahanan lapangan dilaksanakan di Desa Alam Endah Rancabali Ciwidey pada ketinggian $\pm 1.200 \mathrm{~m}$ di atas permukaan laut (DPL). Lokasi penelitian merupakan daerah endemik penyakit hawar daun Phytophthora, karena lokasi tersebut, selalu digunakan untuk penanaman kentang dan penyakit hawar daun selalu dilaporkan terjadi. Pupuk buatan yang diberikan adalah NPK 16:16:16 sebanyak $1200 \mathrm{~kg} / \mathrm{ha}$, ditambah pemberian pupuk kandang saat penanaman sebanyak 30 ton/ha. Jarak tanam yang digunakan $80 \mathrm{~cm}$ x $30 \mathrm{~cm}$. Penelitian dilaksanakan pada waktu musim hujan agar keadaan lingkungan kondusif untuk pertumbuhan tanaman kentang dan untuk terjadinya infeksi dan pertumbuhan sporangium $P$. infestans. Parameter yang diamati adalah intensitas penyakit hawar daun, dimulai dari tiga minggu setelah tanam, selanjutnya diamati setiap 1 minggu sekali sampai total pengamatan sebanyak 7 kali pengamatan.

Pengamatan dilakukan terhadap intensitas penyakit dan perkembangan penyakit. Skor ketahanan tanaman diamati berdasarkan persentase daun terserang menggunakan sistem skoring 0 - 9 (Halterman et al., 2008) seperti pada Tabel 1. Intensitas penyakit (\%) dihitung dengan menggunakan rumus:

$$
\mathrm{P}=\frac{\sum \mathrm{nx} \mathrm{v}}{\mathrm{N} \times \mathrm{Z}} \times 100 \%
$$

Keterangan:

$\mathrm{P}=$ intensitas penyakit

$\mathrm{n}=$ jumlah tanaman dari tiap kategori serangan

$\mathrm{v}=$ nilai skala dari tiap kategori serangan

$\mathrm{N}=$ jumlah tanaman contoh

$\mathrm{Z}=$ skor dari kategori serangan tertinggi

Untuk menentukan bagaimana perkembangan penyakit pada setiap klon dan varietas tanaman yang diuji, data intensitas penyakit setiap minggu diplotkan terhadap waktu pengamatan untuk mendapatkan kurva perkembangan penyakit. Untuk keperluan analisis statistik, luas area di bawah kurva perkembangan penyakit (Area Under Diseases Progress Curve, AUDPC), dihitung menggunakan rumus sebagai berikut (Landeo, 1999):

$$
\mathrm{n}
$$

$\mathrm{AUDPC}=\sum_{\mathrm{i}=1}\left(\mathrm{X}_{\mathrm{t}+1}+\mathrm{X}_{\mathrm{t}}\right)\left(\mathrm{D}_{\mathrm{t}+1}-\mathrm{D}_{\mathrm{t}}\right)$ 
Keterangan :

$\mathrm{X}_{\mathrm{t}}=$ persentase serangan hawar daun pengamatan pada waktu ke-t

$\mathrm{X}_{\mathrm{t}+1}=$ persentase serangan hawar daun pada pengamatan $t+1$ pengamatan berikutnya

$\left(D_{t+1}-D_{t}\right)=$ interval pengamatan dari pengamatan pertama ke pengamatan kedua
Data AUDPC kemudian dihitung dengan Sidik Ragam (Uji F) menggunakan program SPSS versi 17 (Yamin \& Kurniawan, 2009) dan dilanjutkan dengan uji LSD (uji beda nyata terkecil) pada taraf nyata $5 \%$.

Tabel 1. Skoring ketahanan berdasarkan persentase daun terserang $P$. infestans (Halterman et al., 2008).

\begin{tabular}{ccl}
\hline Skor & \% daun terserang & \multicolumn{1}{c}{ Deskripsi } \\
\hline 0 & 0 & Tidak ada gejala serangan \\
1 & $<10$ & $\begin{array}{l}\text { Bercak-bercak serangan kurang dari 10\% pada daun } \\
\text { Bercak-bercak kerusakan mulai tampak dan mencapai 25\% } \\
\text { Bercak-bercak kerusakan pada seluruh daun mencapai } 40 \% \text { tetapi tanaman } \\
\text { masih hijau }\end{array}$ \\
3 & $11-25$ & Kerusakan maksimal sudah mencapai 60\% \\
4 & $26-40$ & $\begin{array}{l}\text { Kerusakan masksimal sudah mencapai 70\% dan tanaman kelihatan coklat } \\
\text { Kerusakan maksimal sudah mencapai 80\%, pangkal batang dan pucuk } \\
\text { terseran dan gejala layu dan mati }\end{array}$ \\
6 & $41-60$ & $\begin{array}{l}\text { Kerusakan maksimal mencapai 90\%, bagian yang berwarna hijau hanya } \\
\text { bagian pucuk } \\
\text { Daerah yang berwarna hijau tinggal sedikit. } \\
\text { Sudah tidak ada lagi daun yang berwarna hijau, kerusakan sudah } \\
\text { menyeluruh }\end{array}$ \\
9 & $71-70$ &
\end{tabular}

\section{HASIL DAN PEMBAHASAN}

Hasil pengujian ketahanan 6 klon kentang hasil persilangan antara var. Atlantic dengan var. Repita terhadap penyakit hawar daun $P$. infestans di
Ciwidey Kabupaten Bandung (Tabel 2), menunjukkan bahwa secara statistik tidak ada klon yang memperlihatkan ketahanan setara dengan var Repita sebagai tetua tahannya.

Tabel 2. Nilai AUDPC hasil uji ketahanan terhadap penyakit hawar daun di Ciwidey.

\begin{tabular}{|c|c|c|c|c|c|}
\hline \multirow{2}{*}{ Genotipe } & \multicolumn{3}{|c|}{ AUDPC pada Ulangan } & \multirow{2}{*}{$\begin{array}{l}\text { Rerata } \\
\text { AUDPC }\end{array}$} & \multirow{2}{*}{ Kriteria Ketahanan } \\
\hline & 1 & 2 & 3 & & \\
\hline AR 04 & 160,1 & 155,5 & 154,3 & $156,6 \mathrm{~d}$ & Agak tahan \\
\hline AR 05 & 109,3 & 113,6 & 114,9 & $112,6 \mathrm{c}$ & Agak tahan \\
\hline AR 06 & 182,8 & 188,6 & 189,2 & $186,9 \mathrm{e}$ & Agak tahan \\
\hline AR 07 & 103,2 & 102,5 & 101,1 & $102,3 \mathrm{~b}$ & Agak tahan \\
\hline AR 08 & 99,5 & 96,0 & 95,8 & $97,1 \mathrm{~b}$ & Tahan \\
\hline AR 09 & 208,1 & 211,6 & 209,0 & $209,6 \mathrm{f}$ & Agak tahan \\
\hline Atlantic & 279,7 & 282,6 & 280,3 & $280,9 \mathrm{~g}$ & Rentan \\
\hline Repita & 54,0 & 51,6 & 49,3 & $51,6 \mathrm{a}$ & Tahan \\
\hline Granola & 147,9 & 152,8 & 150,0 & $150,2 \mathrm{~d}$ & Agak tahan \\
\hline
\end{tabular}

Setiap klon kentang hasil persilangan antara var. Atlantic $\mathrm{x}$ var. Repita memperlihatkan adanya variasi tingkat ketahanan terhadap penyakit hawar daun. Klon AR 07 dan klon AR 08 menunjukkan tingkat ketahanan yang lebih baik dibanding klon kentang hasil persilangan lainnya, walaupun tingkat ketahanannya juga masih di bawah var. Repita.
Namun berdasarkan kriteria tingkat ketahanan menggunakan nilai AUDPC yang diusulkan oleh Sinaga (2003) sebagaimana disajikan pada Tabel 3, hanya klon AR 08 yang dapat dikategorikan sebagai klon kentang yang tahan, karena secara statistik angka AUDPC klon AR 8 tidak berbeda nyata dengan angka AUDPC var. Repita, sehingga dapat 
dikategorikan sama-sama "tahan" dengan var. Repita. Sementara itu, klon kentang hasil persilangan lainnya termasuk dalam kriteria "agak tahan". Tidak ada klon kentang hasil persilangan yang termasuk kategori rentan berdasarkan kriteria Sinaga (2003) tersebut. Apalagi secara statistik, besaran AUDPC masing-masing klon hasil persilangan tidak ada yang sama dengan besaran AUDPC var. Atlantic, sebagai check rentan.

Tabel 3. Kriteria tingkat ketahanan berdasarkan nilai AUDPC (Sinaga, 2003).

\begin{tabular}{lc}
\hline \multicolumn{1}{c}{ Kategori } & Nilai AUDPC \\
\hline Sangat Tahan & $0,0-50,0$ \\
Tahan & $50,1-100,0$ \\
Agak Tahan & $100,1-250,0$ \\
Rentan & $>250,0$ \\
\hline
\end{tabular}

Kedua klon tersebut diduga memiliki gen pengendali ketahanan yang diturunkan dari Repita. Gen ini berperan dalam pembentukan enzim chitinase dan $\beta$-1,3-glucanase yang merupakan senyawa yang biasa diproduksi tanaman jika mendapat infeksi patogen (Pieterse et al., 1992). Di antara kedua enzim pertahanan sebagaimana yang dikemukakan oleh Pieterse et al. (1992) tersebut, dapat diduga bahwa enzim $\beta$-1,3-glucanase nampaknya merupakan enzim yang paling berperan dalam mendegradase dinding sel $P$. infestans. Hal ini didasarkan kepada fakta bahwa $P$. infestans dinding selnya mengandung senyawa glucan dan tidak mengandung senyawa chitin (Pieterse et al., 1992). Hal ini dijelaskan pula oleh studi yang dilakukan oleh Abd-El-Kareem et al. (2001) yang melaporkan bahwa pada tanaman kentang yang tahan, terjadi peningkatan aktifitas enzim $\beta$-1,3-glucanase ketika terinfeksi oleh $P$. infestans.

Dalam penelitian ini, ketahanan klon kentang terhadap penyakit hawar daun yang disebabkan oleh $P$. infestans, dievaluasi dengan melihat perkembangan penyakit hawar daun yang menginfeksi tanaman klon kentang tersebut. Perkembangan nilai keparahan penyakit digunakan sebagai dasar menentukan tingkat ketahanan dari setiap klon yang diuji berdasarkan rumus AUDPC (Listanto et al., 2013). Intensitas penyakit tidak dianalisis berdasarkan data setiap kali pengamatan, karena menurut Agrios (2005) perkembangan penyakit merupakan suatu proses yang berkelanjutan dan merupakan hasil dari proses interaksi yang terus-menerus antara patogen dengan tanaman. Dalam bidang ilmu penyakit tumbuhan, AUDPC sudah merupakan standar yang digunakan untuk melihat perkembangan penyakit dari waktu ke waktu (Landeo, 1999, Simko \& Piepho, 2012). Untuk mengetahui perbedaan besaran AUDPC, analisis statistik dapat dipergunakan dengan membandingkan besaran AUDPC antar perlakuan atau klon. Semakin berkembang penyakitnya, semakin besar nilai AUDPC. Sebaliknya, semakin rendah nilai AUDPC, maka semakin rendah pula perkembangan penyakitnya (Suganda, 2001), yang salah satunya disebabkan oleh perlawanan gen ketahanan tanaman. Dalam kata lain, dalam pengujian ini, semakin rendah nilai AUDPC menandakan semakin tinggi ketahanan tanaman kentang terhadap penyakit hawar daun $P$. infestans. Berdasarkan hasil penelitian, terlihat bahwa gen ketahanan tanaman kentang terhadap $P$. infestans yang dimiliki oleh var. Repita berhasil diturunkan ke klon-klon hasil persilangannya dengan var. Atlantic, walaupun sepertinya gen ketahanan tersebut tidak bersifat dominan.

\section{SIMPULAN}

Dari hasil penelitian yang telah dilaksanakan, dapat diambil simpulan sebagai berikut:

1. Dari keenam klon hasil persilangan antara var. Atlantic x var. Repita klon-klon AR 04, AR 05, AR 06, AR 07 dan AR 09 memperlihatkan reaksi agak tahan, sedangkan klon AR 08 memperlihatkan reaksi tahan terhadap $P$. infestans isolat Ciwidey, walaupun berdasarkan nilai AUDPC-nya, sifat ketahanannya masih di bawah var. Repita sebagai tetua tahannya.

2. Sifat ketahanan berhasil diturunkan dari var. Repita sebagai tetua tahan, namun tidak sepenuhnya dominan.

\section{DAFTAR PUSTAKA}

Abd-El-Kareem, F, MA Abd-Alla, and RSR ElMohamedy. 2001. Induce resistance in potato plants for controlling late blight disease under field conditions. Egypt. J. Phytopathol. 29(2): 29-41.

Halterman, DA, LC Kramer, S Wielgus, and J Jiang. 2008. Performance of transgenic potato containing the late blight resistance gene RB. Plant Dis. 92(3): 339-343.

Hariyadi, Y, and Koentjoro. 1996. Penampakan galur-galur kentang (Solanum tuberosum. L) resisten terhadap penyakit hawar daun (Phytophthora infestans Mont.d.By). 
Prosiding Simposium Pemuliaan Tanaman IV; UPN Jatim, 24-25 Mei 1996. Hlm. 241-248.

Kusmana. 2003. Evaluasi beberapa klon kentang asal stek batang untuk uji ketahanan terhadap Phytophthora infestans. J. Hort. 13(4): 220228.

Landeo, JA. 1999. Data processing and interpretation of resistance parameters. The International Potato Centre (CIP) PERU [unpublished].

Listanto, E, M Herman, dan E Sofiari. 2013. Uji ketahanan galur-galur kentang transgenik hasil transformasi dengan gen $\mathrm{RB}$ terhadap penyakit hawar daun (Phytophthora infestans) di KP Pasirsarongge, Cianjur. J. HPT Tropika. 13(2): 141-150.

Pieterse, CMJ, PJGM De Wit, and FPM Govers. 1992. Molecular aspects of the potato Phytophthora infestans interaction. Netherland Journal of Plant Pathology. 96(2): 85-92.

Rietman, H, G Bijsterbosch, LM Cano, HR Lee, JH Vossen, E Jacobsen, RGF Visser, S Kamoun, and VGAA Vleeshouwers. 2012. Qualitative and quantitative late blight resistance in the potato cultivar Sarpo Mira is determined by the perception of five distinct RXLR effectors. Mol. Plant Microbe Interact. 25(7): 910-919.

Sedláková, V, J Dejmalová, E Hausvater, P Sedlák, P Doležal, and J Mazáková. 2011. Effect of Phytophthora infestans on potato yield in dependence on variety characteristics and fungicide control. Plant Soil Environ. 57(10): 486-491.

Sinaga, MS. 2003. Dasar-dasar Ilmu Penyakit Tumbuhan. Seri Agriteks. Penebar Swadaya, Depok.

Simko, I, and HP Piepho. 2012. The area under the disease progress stairs: Calculation, advantage, and application. Phytopathology. 102: 381389.

Song, J, JM Bradeen, SK Naess, JA Raasch, SM Wielgus, GT Haberlach, J Liu, H Kuang, SA Phillips, CR Buell, JP Helgeson, and J Jiang. 2003. Gene RB cloned from Solanum bulbocastanum confers broad spectrum resistance to potato late blight. Proc. Natl. Acad. Sci. 100(16):9128-9133.

Suganda, T. 2001. Penginduksian resistensi tanaman kacang tanah terhadap penyakit karat (Puccinia arachidis Speg.) dengan pengaplikasian asam salisilat, asam asetat etilendiamintetra, kitin asal kulit udang, air perasan daun melati, dan dikaliumhidrogenfosfat. Agrikultura. 12(2): 83-88.

Yamin, S, and H Kurniawan. 2009. SPSS Complete: Teknik Analisis Statistik Terlengkap dengan Software SPSS. Buku Seri Pertama. Salemba Infotek, Jakarta. $70 \mathrm{Hlm}$. 